(C)2016 IEEE. Reprinted, with permission, from M. Patil, T.Y. Abukhalil, S. Patel, and T.M. Sobh, "UB Robot Swarm - Design, Implementation, and Power Management.” In Proceedings of 12th IEEE International Conference on Control and Automation (ICCA), Katmandu, Nepal, 2016. DOI: 10.1109/ICCA.2016.7505339.

This material is posted here with permission of the IEEE. Such permission of the IEEE does not in any way imply IEEE endorsement of any of the University of Bridgeport's products or services. Internal or personal use of this material is permitted. However, permission to reprint/republish this material for advertising or promotional purposes or for creating new collective works for resale or redistribution must be obtained from the IEEE by writing to pubs-permissions@ieee.org. By choosing to view this document, you agree to all provisions of the copyright laws protecting it. 


\title{
UB Robot Swarm - Design, Implementation, and Power Management
}

\author{
Madhav Patil, Tamer Abukhalil, Sarosh Patel, and Tarek Sobh
}

\begin{abstract}
In this paper we describe the hardware architecture of an inexpensive, heterogeneous robot swarm, designed and developed at the RISC lab, University of Bridgeport. Each swarm robot is equipped with sensors, actuators, control and communication units, power supply, and interconnection mechanism. This article also describes the essential features and design of a power distribution and management system for a dynamically reconfigurable system. It further presents the empirical results of the proposed power management system collected with the real robotic applications.
\end{abstract}

Keywords-Heterogeneous Robot Swarm; Hardware Architecture; Power Distribution in Robot Swarm.

\section{INTRODUCTION}

Swarm robotics is inspired from animals that behave in a group such as insects, ants and bees. Till date, most existing swarm robotic systems have been designed and implemented with homogeneous hardware. Only a few of them are heterogeneous in nature, but such swarm systems are limited physically and behaviorally. Due to such lack of methods and tools, swarm robot designers cannot achieve the complexity required for the real world applications [1]. The complexity of designing and physically implementing the heterogeneous swarm is greater when compared to the homogeneous robot swarms. There are several aspects involved in the development of swarm hardware, such as locomotion, actuation, navigation, size, appropriate sensors, cost, and communication $[2,3]$. One of the challenges for robot swarms is its autonomy, the robot must be aware of its battery life, localization etc. In our review article [3], we have reviewed the hardware architecture of existing robot swarm system with respect to self-configurability, self-assembly, and selfreplication. After reviewing existing swarm systems and studying the limitations, we decided to design and built our own robot swarm. In this design we have considered some important factors such as size, cost, autonomy, flexibility, robustness, power consumption, weight, etc. The main goal of our research is to build a heterogeneous robot swarm in which each robot has distinct hardware. The proposed architecture is an autonomous, modular and self-configurable. Nowadays electronic products are cheaper, smaller,

\footnotetext{
* Madhav Patil, is with the RISC Lab, School of Engineering, University of Bridgeport, CT 06604 USA e-mail: mpatil@my.bridgeport.edu.

Tamer Abukhalil, is with the RISC Lab, School of Engineering, University of Bridgeport, CT 06604, USA e-mail: tabukhal@my.bridgeport.edu.

Sarosh Patel, is with the RISC Lab, School of Engineering, University of Bridgeport, CT 06604 USA e-mail: saroshp@ bridgeport.edu.

Tarek Sobh, is dean of the RISC Lab, School of Engineering and the University vice president, University of Bridgeport, CT 06604 USA e-mail: sobh@bridgeport.edu.
}

lighter in weight and easily available, which makes robot swarms more cost efficient, lighter in weight, and compact in size $[4,5]$.

The swarm-bot research project [6], deals with design and implementation of swarm robots (s-bots) with self organizing and self assembling capabilities, but each S-bot is physically identical (homogeneous) and uses same kind of sensors, actuators, microcontroller. S-bot can connect with other S-bots with rigid gripper and also able to lift the other S-bots to create bigger structure. Further, they extended the swarm-bots into swarmanoid project, which focused on the study, design and implementation of swarm of heterogeneous robots [1]. In this case, a swarm includes robots that can move on the ground, fly and climb on vertical surface. In swarmanoid project, robots use different colored light emitting diodes (LED) and omnidirectional camera for communicating with each other. The camera is pointed at a half spherical mirror to directly acquire images from its surroundings. The problem with swarm bot is that, the images that camera receives are further away than seen in mirror. Table I summarizes the hardware platforms implemented so far in swarm robot research experiments. The hardware platforms given in the above Table I are homogeneous in nature with capabilities and functionality.

The power distribution management in a swarm robot is very important, and depends not only on the electronic design but also on its mechanical structure. To perform a task in an unknown environment, robots should be capable of great degree of autonomy and operate over a longer time. The autonomous mobile robots draw power from batteries carried on the chassis in order to provide the power to the onboard sensors, actuators, and communication modules. Batteries have a limited lifetime, due to which the operational time of the robots in the swarm is also limited. For successful completion of the tasks, the robot swarm must be continuously aware of the lifetime of its power source; therefore, management of power resources is necessary and vital for spending the available energy economically.

In section 2 we have explained the hardware architecture and the design goals of the UB swarm. Section 3 describes the sensory platform and their technical specifications and working principles. Section 4 describes the locomotion and manipulation units. Section 5 describes the communication and control units used on the UB swarm. Section 6 shows experimental results of human rescue task using the UB robot swarm. 
TABLE I HARDWARE PLATFORM SUMMARY

\begin{tabular}{|c|c|c|c|c|c|c|}
\hline Sr. No & Name & Sensor & $\begin{array}{l}\text { Actuati } \\
\text { on }\end{array}$ & \begin{tabular}{|l} 
Controll \\
er
\end{tabular} & $\begin{array}{l}\text { Commun } \\
\text { ication }\end{array}$ & $\begin{array}{l}\text { Positioni } \\
\text { ng system }\end{array}$ \\
\hline 1 & E Puck & $\begin{array}{l}11 \mathrm{IR}, \\
\text { Contact } \\
\text { ring, Color } \\
\text { camera }\end{array}$ & wheeled & dsPIC & Bluetooth & $\begin{array}{l}\text { Expansion } \\
\text { IR based }\end{array}$ \\
\hline 2 & Alice & $\begin{array}{l}\text { IR, Light } \\
\text { Sensor, } \\
\text { Linear } \\
\text { Camera }\end{array}$ & Wheeled & $\begin{array}{l}\text { Microchi } \\
\text { p PIC }\end{array}$ & $\begin{array}{l}\text { Radio } \\
(115 \\
\text { kbit/s })\end{array}$ & ------ \\
\hline 3 & Jasmine & 8 IR & wheeled & 2 & IR & $\begin{array}{l}\text { Integrated } \\
\text { IR based }\end{array}$ \\
\hline 4 & I-swarm & Solar cell & $\begin{array}{l}3 \text { micro } \\
\text { leg } \\
\text { piezoele } \\
\text { ctric } \\
\text { actuator }\end{array}$ & $\begin{array}{l}\text { Not } \\
\text { Availabl } \\
\text { e }\end{array}$ & $\begin{array}{l}\text { Not } \\
\text { Available }\end{array}$ & ----- \\
\hline 5 & Khepera & 8 IR & wheeled & \begin{tabular}{|l} 
Motorola \\
MC6683 \\
1
\end{tabular} & $\begin{array}{l}\text { RS232, } \\
\text { Wired } \\
\text { link }\end{array}$ & ---- \\
\hline 6 & $\begin{array}{l}\text { Khepera } \\
\amalg\end{array}$ & $\begin{array}{l}11 \mathrm{IR}, 5 \\
\text { Ultrasound }\end{array}$ & wheeled & $\begin{array}{l}\text { PXA- } \\
255, \\
\text { Linux, } \\
\text { dsPIC }\end{array}$ & $\begin{array}{l}\text { WiFi \& } \\
\text { Bluetooth }\end{array}$ & $\begin{array}{l}\text { Expansion } \\
\text { IR based }\end{array}$ \\
\hline 7 & S-Bot & $\begin{array}{l}15 \\
\text { Proximity, } \\
\text { Omnidirecti } \\
\text { onal } \\
\text { Camera, } \\
\text { Microphone } \\
\text { Temperatur } \\
\text { e }\end{array}$ & $\begin{array}{l}\text { Wheeled } \\
\quad 2 \\
\text { gripper }\end{array}$ & $\begin{array}{l}\text { Xscale } \\
\text { Linux } \\
\text { PICs }\end{array}$ & WiFi & $\begin{array}{l}\text { Camera } \\
\text { based }\end{array}$ \\
\hline 8 & $\begin{array}{l}\text { SwarmB } \\
\text { ot }\end{array}$ & $\begin{array}{l}\text { IR, Camera, } \\
\text { Light, } \\
\text { Contact }\end{array}$ & Wheeled & $\begin{array}{l}\text { ARM } \\
\text { and } \\
\text { FPGA } \\
200 \\
\text { kgate }\end{array}$ & IR based & $\begin{array}{l}\text { Integrated } \\
\text { IR based }\end{array}$ \\
\hline 9 & Kobot & $\begin{array}{l}8 \mathrm{IR}, \text { Color } \\
\text { camera }\end{array}$ & wheeled & $\begin{array}{l}\text { PXA- } \\
\text { 255, } \\
\text { PICs }\end{array}$ & ZigBee & $\begin{array}{l}\text { Integrated } \\
\text { IR based }\end{array}$ \\
\hline
\end{tabular}

\section{HARDWARE DESIGN}

The hardware design for any swarm system is an interactive and an important phase. At the hardware level, the most work has been done in collective behavior with homogeneous robots. In this project we decided to exploit reconfigurability, and modularity using heterogeneous robots with decentralized control algorithms. This swarm of heterogeneous robots is designed for real world applications in order to perceive their environmental physical properties through sensors and do manipulation using actuators. This modular hardware architecture consists of independent sensory units, actuator modules, and communication units, that make swarm system scalable and flexible such that more sensors and/or actuators can be added without modifying the overall architecture. Fig. 1 shows an overview of the hardware design implementation.

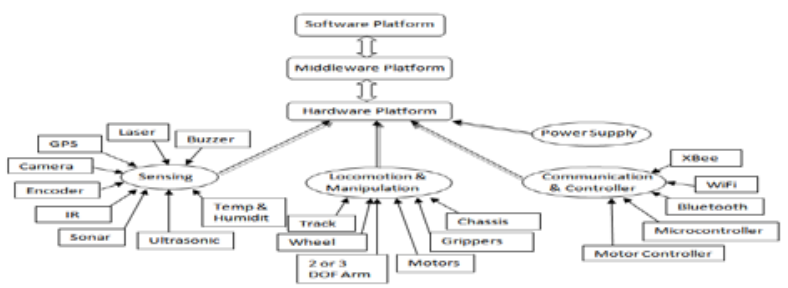

Fig. 1 Hardware Architecture Design

There are many things that have to be considered while designing and implementing the hardware platform for the heterogeneous swarm. Following are the design goals for UB swarm:

- Should consume less power.

- Should provide user friendly mobile, modular, and flexible platform.

- They should be reconfigurable and provide easy support for the software as well as for the middleware.

- They should provide low cost wireless communication for indoor as well as outdoor applications

- They should have enough future expansion space for sensory units and actuators.

- Each robot should be fully functional, and continuously coordinate and communicate with other robots.

Building of such a heterogeneous swarm of robots is a really difficult task. At the time of writing this paper we have built five swarm robots, which are fully assembled and tested for mapping, obstacle avoidance, painting, and rescue application. The UB robot swarm is simple, capable of sensing, localization, and actuation based on the local information and basic swarm rules. In the following sections, the mechanical and electronic modules of the robots are described with their working. All the parts were tested and slightly modified for the applications, and then assembled to build the physical robots swarm. 


\section{SENSORS}

Gathering data about the working environment or of the robot is an everlasting job. The sensory unit is important for performing the tasks such as obstacle detection, obstacle avoidance, detecting its neighboring robot, and navigation [6]. Sensors are classified as five sensing elements of the robot and are used to collect sensory data about their surrounding. In UB Swarm hardware design, each swarm robot is equipped with different types of sensors such as temperature sensor, humidity sensors, encoder, camera, proximity sensors, ranger detector, GPS tracking devices, etc.

The study of animal behavior shows that, the sensory skills are developed and adapted by the interpretation of signals generated from sensors. In swarm robots, this self learning capability is achieved by configuring and calibrating sensors for a given task. Using multiple sensors provides the most efficient and effective methods for collecting, and investigating the unknown environments.

\section{A. Proximity Sensors}

In swarm robotics, obstacle detection and collision avoidance in real time while the robots are in motion is major constrain. Proximity sensors sense the object or surrounding material or other moving swarm robots without any physical contact, and calculate the precise distance of that object [8]. This crucial component not only avoids collision, but also prevents the physical damage to the swarm robots and maintains safe distance $[2,3]$. Depending on the type of technology used, proximity sensors are classified into different categories such as, inductive, capacitive, photoelectric, and ultrasonic proximity sensors.

Among these, ultrasonic proximity sensors were found to be more accurate and have more capabilities when compared to the others types of proximity sensors [3]. In the UB swar, we use ultrasonic as well as photoelectric (Infrared) proximity sensors.

\section{1) Ultrasonic Sensor}

Ultrasonic sensors are very commonly used to measure distance because they are inexpensive and easy to handle. They are used to avoid obstacles, to navigate, and for map building. Ultrasonic sensors emit sound waves (ultrasound) of $20 \mathrm{KHz}$ frequency. This sensor sends outs ultrasonic waves which are then detected after they are reflected or bounced back from object and/or obstacle. The time required for sending and to receiving the ultrasonic waves is measured and further processed to calculate the distance. Following are the ultrasonic sensors used in UB robot swarm system with their technical specifications.

- Devantech SRF02 - We use the SRF02 in Serial mode, the mode pin is connected to $0 \mathrm{v}$ Ground. The Rx pin is data into the SRF02 and connected to the Tx pin on PIC controller. The Tx pin is data out of the SRF02 and connected to the Rx pin on PIC controller.

- Seeedstudio Ultrasonic Range Finder - This sensor operates on 5VDC voltage, $15 \mathrm{~mA}$ current and the maximum measuring range is $400 \mathrm{~cm}$. The data pin of sensor is connected to the digital pin of microcontroller.
- Ping Ultrasonic Sensor - The output from the ping sensor is a variable-width pulse that corresponds to the distance to target. The GND pin is connected to the GND of the microcontroller, 5 VDC is connected to the 5 VDC power supply and the signal pin is connected to the analog pin of the micro controller.

- LV-MaxSonar-EZ1 MB1010 Sensor - The analog pin of the sensor is connected to the analog pin of the controller. The analog voltage pin outputs a voltage which corresponds to the distance. The distance of an object from the sensor is directly proportional to the voltage.

\section{2) Infrared Sensors}

The IR Range Finder works by the process of triangulation. A light pulse of wavelength range $850 \mathrm{~nm}$ $(+/-70 \mathrm{~nm})$ is emitted from the sensor and then reflected back by an object or not reflected at all. When the light returns it comes back at an angle that is dependent on the distance of the reflecting object as shown in fig. 2. Triangulation works by detecting this reflected beam angle and by knowing the angle, the distance can then be determined. The performance of the IR sensor is limited by its poor tolerance to the ambient light or bright object color reflection. The output of the IR sensors is analog, which is connected to the analog pin of the microcontroller. The Sharp IR Range FinderGP2Y0A02YK0F and Dagu compound infrared sensor are used in UB swarm robot system.

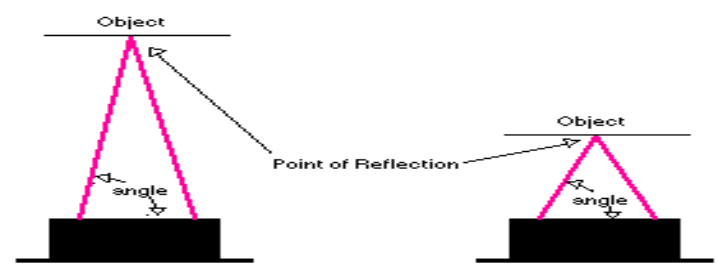

Fig. 2 IR Triangulation Method

\section{B. Encoder}

To determine the exact position or location of the robot; odometry is more reliable, very precise technique and inexpensive. Encoder counts the number of pulses for every rotation of the wheel and from that rotation of wheel, distance can be calculated. The encoder has the IR reflective sensors which read the black and white strips on the encoder wheel. The encoder wheel is attached to the shaft and the sensor unit is mounted on the chassis. When the shaft rotates, the encoder wheel also rotates and the sensor board starts counting the revolutions [9]. The encoder shown in fig. 3 is mounted on the chassis with micro metal gear motor. This encoder has two IR reflective sensors with a phase difference of 90 degrees and the lead - lag of the waveform will decide the forward and reverse rotation of the wheel. This encoder works on $3.3-5$ VDC voltage and the pulse output is 48 pulses per revolution. 


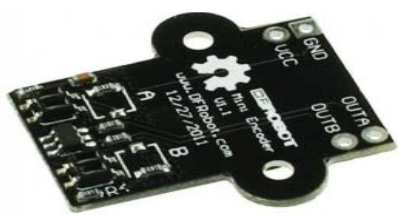

Fig. 3 DFRobot Encoder

\section{GPS/GPRS/GSM Module}

Solving a task which is beyond the capability of the single robot, requires cooperation from the other swarm robots. For such a cooperative task, robots must communicate with each other and know their relative position and orientation [10]. To achieve the heterogeneity of swarm system, one of the robot uses the GPS/GPRS/GSM module shield, while other robots use encoders, vision navigation to send its relative position to the other robots as well as to the host computer. This shield with a Quad-band GSM/GPRS engine works on frequencies EGSM $900 \mathrm{MHz} / \mathrm{DCS} 1800 \mathrm{MHz}$ and GSM850 MHz/PCS $1900 \mathrm{MHz}$. It also supports GPS technology for satellite navigation.

\section{Camera}

The camera module provides vision based localization and obstacle avoidance in the swarm system. We use Blackfin Camera with Radio/Motor Board on our robot swarm. This camera can transmit the live feed to the host computer over wireless communication. In differentiating between the obstacle and goal objects, IR sensor and ultrasonic sensor have some limitations, which can be rectified by using the camera module. We can view the images on the host computer or we can also feed them to the microcontroller with the onboard image processing unit. This camera is mounted on the SRV1 platform and DF robot rover platform.

\section{LOCOMOTION AND MANIPULATION}

The biggest challenge in developing the robot swarm is to make them mobile, fully autonomous and versatile so that they can move from one place to another over different types of terrains in an unknown environment. The locomotion of robot can be achieved by the motors with some gear ratio to slow down the speed of rotation and increase the torque. In manipulation, objects are moved from one place to another with the help of actuators and we also use the motors to rotate the wrist or open and close the gripper to grab the objects. In our previous work [3], the locomotion and manipulation of different robot platforms is explained in detail. In this section, we explain the type of motors used and their connection and control mechanism with microcontroller. The robot swarm uses track and wheel for locomotion and for manipulation uses robot arm which are driven by the DC motors, Geared DC motors, and Servo Motors.

\section{A. Motors}

The drive motor is selected based on the voltage, RPM, brushed or brushless parameters. The UB swarm robots are driven by motors which are attached to the wheel. On each robot, two motors are attached to the wheels along with encoder modules. We used DC gear motors; Solarbotics gear motors, Micro-metal gear motors, Tamiya gearbox motors.
These motors are actuated and controlled using the motor controllers. The specification of the motors used on swarm robots is given in Table Ш.

TABLE II SPECIFICATION OF MOTORS

\begin{tabular}{|c|c|c|c|}
\hline $\begin{array}{l}\text { Tamiya Twin- } \\
\text { Motor }\end{array}$ & $\begin{array}{l}\text { Micro Metal } \\
\text { Gear Motor }\end{array}$ & $\begin{array}{l}\text { Solarbotics } \\
\text { GM9 Gear } \\
\text { Motor }\end{array}$ & $\begin{array}{l}\text { Hitec HS-422 } \\
\text { Servo Motor }\end{array}$ \\
\hline $\begin{array}{l}\text { Gear ratios: } \\
58: 1\end{array}$ & $\begin{array}{l}\text { Gear ratio: } \\
50: 1\end{array}$ & $\begin{array}{ll}\text { Gear } & \text { ratio: } \\
143: 1 & \end{array}$ & $\begin{array}{ll}\text { Speed: } & 0.16 \\
\text { sec/60o } & \end{array}$ \\
\hline $\begin{array}{l}\text { Motor } \\
\text { RPM: } 12300\end{array}$ & $\begin{array}{l}\text { Motor RPM: } \\
13000\end{array}$ & $\begin{array}{l}\text { Motor RPM: } \\
78\end{array}$ & $\begin{array}{l}\text { Pulse Width } \\
\text { Control }\end{array}$ \\
\hline $\begin{array}{l}\text { Voltage: } 1.5- \\
\text { 3VDC }\end{array}$ & $\begin{array}{l}\text { Voltage: } \\
\text { 6VDC }\end{array}$ & $\begin{array}{l}\text { Voltage: } \\
6 \text { VDC }\end{array}$ & $\begin{array}{l}\text { Voltage: } \quad 4-6 \\
\text { VDC }\end{array}$ \\
\hline
\end{tabular}

\section{B. Motor Controller}

We use the motor controller to drive the wheel motors in addition to the microcontroller. The fig. 4 shows the Pololu low voltage dual motor controller which is mounted on Rover 5 to control the speed and direction of the wheel motors. This low voltage dual motor controller is specially designed for the motors which require low voltage, high current to drive. The left side motor's positive terminal (Black wire) is connected to $\mathrm{M} 0+$ and negative terminal (Red wire) is connected to the M0of the motor controller. The right side motor's positive terminal is connected to the $\mathrm{M} 1+$ and negative terminal connected to the M1- on the motor controller. The Vcc terminal of motor controller is connected to the $5 \mathrm{~V}$ on microcontroller. The GND of the battery, motor controller and microcontroller are connected to each other. The SER pin of the motor controller is connected to the Pin 1-Tx pin of the microcontroller and RST on motor controller is connected to the RST pin on microcontroller. The complete wiring diagram for the motor controller and microcontroller of Rover 5 is shown in fig. 4 .

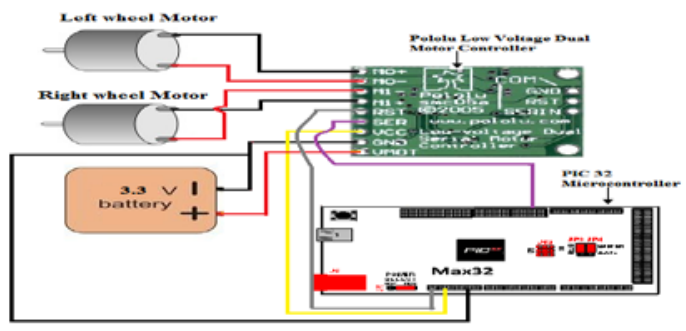

Fig. 4 Motor Controller Wiring

\section{Small Manipulator Arm with Gripper}

To add more flexibility and modularity to the robots, small manipulator arms with grippers are attached on the chassis. These arms with 2 or 3 Degree of Freedom (DOF). The fig. 5 shows images of the small arm with gripper mounted on robot rovers and actuated using Hitec HS-422 Servo Motors. The gripper can grip and can rotate to grab objects or for connecting with other robots in the swarm. The jaws of the gripper can be open up to 1.3 " and the wrist rotates 180 degrees approximately. 


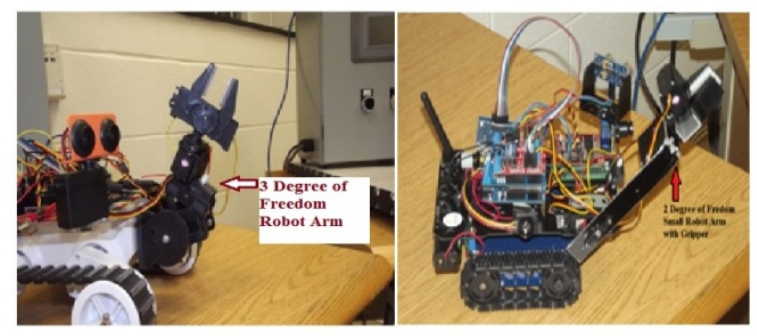

Fig. 5 Small Robot Arm with Gripper

\section{COMMUNICATION AND CONTROL}

\section{A. Communication}

One of the most important factors for efficient cooperative robotics is the communication among them [11]. In our previous survey papers $[3,12]$, we have described all the methods of communication between the robots. Communication depends on the factors such as communication range, environment, size of the swarm system, type of information to be sent/received etc. In [13], the comparison between two well known communication types - implicit and explicit has been made. For communication, each robot swarm is equipped either with X-Bee module or Bluetooth Bee module or PmodWiFi module. X-Bee series 1, Bluetooth Bee and PmodWiFi are compatible to each other and use the same communication protocol. The X-Bee and Bluetooth Bee use the serial transfer mode (Tx and Rx) while the PmodWiFi uses SPI mode for transmitting and receiving the data.

The PmodWiFi module uses SPI bus as a primary interface for communicating with PIC-Max32 microcontroller on Rover 1. The SPI bus uses four signals - SS, MOSI, MISO and SCK which corresponds to the signal selection, data in/ out and clock signal. The INT provides information of data availability and data transfer complete or not to the microcontroller respectively.

\section{B. Control}

The robots in a multi-agent system are controlled using either centralized or decentralized methods. The drawbacks of centralized control has been explained in our previous paper [12], so we decided to use decentralized control method. If the decentralized technique is applied, the hardware structure of robots should be highly redundant, but exploit simple and more robust control strategies. The primary function of a controller is to route and manipulate the communications between other subsystems on the robot such as sensing platform, actuators, navigation system, and localization system. We use PIC32 and Arduino Uno microcontroller for our robot swarm. The PIC controller is a very powerful controller, featuring a 32-bit MIPS processor core running at $80 \mathrm{MHz}, 512 \mathrm{~K}$ of flash program memory and $128 \mathrm{~K}$ of SRAM data memory. In addition, the processor provides a USB 2 OTG controller, 10/100 Ethernet MAC and dual CAN controllers that can be accessed via add-on I/O shields.

Arduino Uno is an open source hardware platform, which adds computational flexibility in our robots. This board based on the ATmega328, has 14 digital input/output pins (of which 6 can be used as PWM outputs), 6 analog inputs, a
$16 \mathrm{MHz}$ ceramic resonator, a USB connection, a power jack, an ICSP header, and a reset button. Ultrasonic sensors as well as sharp IR sensor are connected to the analog input pins, encoders connected to the digital input pins of the controller. This board can be powered by USB port or by 3-6VDC an external power supply. Pin 0 and Pin 1 are used for TTL serial data receiver $(\mathrm{Rx})$ and data transmitter $(\mathrm{Tx})$.

\section{Power Supply}

To keep the swarm running, we need to provide relatively long lasting power to them. We chose rechargeable Nickel Metal Hydride (NiMH) and Lithium Polymer batteries as a power supply for our swarm. These batteries are small in size, lighter in weight and easy to install on the chassis.

Nickel Metal Hydride battery has a high electrolyte conductivity rate that allows for high power applications, and is cheaper than Li-Ion batteries, with high shelf life, but selfdischarge rate is also higher than other batteries. On the other hand Lithium polymer batteries are another form of rechargeable batteries (LiPo) composed of several identical cells in parallel addition which increases discharge current. These batteries are expensive, slim, lighter in weight, and have stable overcharge.

\section{POWER Distribution AND MANAGEMENT}

In a swarm, the cooperation among the individual autonomous robots depends on several design parameters such as communication, and management of resources. The overall power consumption can be calculated by adding the current consumed by each sensor, actuators, microcontroller and all other electronic components that are mounted on the robots. We also have to consider the other factors that affect the power consumption such as its working environment, type of terrain, elevation, how many times gripper closes and pulls an object. The operating current or power of each component can be found from the data sheet provided by manufacturer.

We measured the time for which sensors and actuators will be in use or active and multiply this time by their operating current, for example, if the ultrasonic sensor uses $20 \mathrm{~mA}$ when on, and will be on $80 \%$ of the time, you get $0.8 \times 20 \mathrm{~mA}=$ $16 \mathrm{~mA}$.

TABLE III TOTAL POWER CONSUMPTION FOR ROVER 1

\begin{tabular}{|c|c|c|c|c|c|}
\hline $\begin{array}{c}\text { Sr. } \\
\text { No. }\end{array}$ & Component & Rating & $\begin{array}{c}\text { Current } \\
\text { Operating } \\
\text { Time (\%) }\end{array}$ & $\begin{array}{c}\text { Consumption * } \\
\text { No of } \\
\text { Components }\end{array}$ & Total \\
\hline 1 & $\begin{array}{c}\text { Ultrasonic } \\
\text { Sensors } \\
\text { (SRF02) }\end{array}$ & $4 \mathrm{~mA}$ & $70 \%$ & $2.8 \mathrm{~mA} * 2$ & $\begin{array}{c}5.6 \\
\mathrm{~mA}\end{array}$ \\
\hline 2 & $\begin{array}{c}\text { Ultrasonic } \\
\text { Sensors (URM } \\
\text { V2) }\end{array}$ & $20 \mathrm{~mA}$ & $100 \%$ & $20 \mathrm{~mA}^{* 1}$ & $\begin{array}{c}20 \\
\mathrm{~mA}\end{array}$ \\
\hline 3 & $\begin{array}{c}\text { IR Sensors } \\
\text { (Sharp ) }\end{array}$ & $33 \mathrm{~mA}$ & $50 \%$ & $16.5 \mathrm{~mA} * 1$ & $\begin{array}{c}16.5 \\
\mathrm{~mA}\end{array}$ \\
\hline 4 & $\begin{array}{c}\text { Temp and } \\
\text { Humidity sensor }\end{array}$ & $4 \mathrm{~mA}$ & $10 \%$ & $0.4 \mathrm{~mA} * 1$ & $\begin{array}{c}0.4 \\
\mathrm{~mA}\end{array}$ \\
\hline 5 & $\begin{array}{c}\text { Servos (HS 422 } \\
\text { ) }\end{array}$ & $\begin{array}{c}120 \\
\mathrm{~mA}\end{array}$ & $50 \%$ & $60 \mathrm{~mA} * 4$ & $\begin{array}{c}240 \\
\mathrm{~mA}\end{array}$ \\
\hline 6 & $\begin{array}{c}\text { Wheel Drive } \\
\text { Motors }\end{array}$ & $\begin{array}{c}160 \\
\mathrm{~mA}\end{array}$ & $100 \%$ & $160 \mathrm{~mA} * 1$ & $\begin{array}{c}160 \\
\mathrm{~mA}\end{array}$ \\
\hline
\end{tabular}




\begin{tabular}{|c|c|c|c|c|c|}
\hline 7 & $\begin{array}{c}\text { Microcontroller } \\
\text { (PIC) }\end{array}$ & $90 \mathrm{~mA}$ & $100 \%$ & $90 \mathrm{~mA} * 1$ & $\begin{array}{c}90 \\
\mathrm{~mA}\end{array}$ \\
\hline 8 & Encoders & $4 \mathrm{~mA}$ & $100 \%$ & $4 \mathrm{~mA} * 2$ & $8 \mathrm{~mA}$ \\
\hline 9 & $\begin{array}{c}\text { Motor } \\
\text { Controller }\end{array}$ & $10 \mathrm{~mA}$ & $100 \%$ & $10 \mathrm{~mA} * 1$ & $\begin{array}{c}10 \\
\mathrm{~mA}\end{array}$ \\
\hline 10 & Miscellaneous & $\begin{array}{c}100 \\
\mathrm{~mA}\end{array}$ & $100 \%$ & $100 \mathrm{~mA} * 1$ & $\begin{array}{c}100 \\
\mathrm{~mA}\end{array}$ \\
\hline & & & & Total & $\begin{array}{c}650.5 \\
\mathrm{~mA}\end{array}$ \\
\hline
\end{tabular}

On this rover, a $2000 \mathrm{mAh}$ Lithium-Polymer battery is used to supply the power, and the total power consumed by this rover is $650.5 \mathrm{~mA}$. So the battery lifetime can be calculated as

Battery Life $=$ Battery Capacity / Total power consumed or required for robot

$$
\begin{aligned}
& =2000 \mathrm{mAh} / 650.5 \mathrm{~mA} \\
& =3.07 \mathrm{Hrs} .
\end{aligned}
$$

TABLE IV TOTAL POWER CONSUMPTION FOR ROVER 2

\begin{tabular}{|c|c|c|c|c|c|}
\hline $\begin{array}{c}\text { Sr. } \\
\text { No. }\end{array}$ & Component & Rating & $\begin{array}{c}\text { Operating } \\
\text { Time }\end{array}$ & $\begin{array}{c}\text { Current } \\
\text { Consumption } \\
* \text { No of } \\
\text { Components }\end{array}$ & Total \\
\hline 1 & $\begin{array}{c}\text { Ultrasonic } \\
\text { Sensors (EZ1) }\end{array}$ & $2 \mathrm{~mA}$ & $70 \%$ & $1.4 \mathrm{~mA} * 4$ & $\begin{array}{c}5.6 \\
\mathrm{~mA}\end{array}$ \\
\hline 2 & $\begin{array}{c}\text { IR Sensors } \\
\text { (Sharp) }\end{array}$ & $33 \mathrm{~mA}$ & $50 \%$ & $16.5 \mathrm{~mA} * 1$ & $\begin{array}{c}16.5 \\
\mathrm{~mA}\end{array}$ \\
\hline 3 & $\begin{array}{c}\text { X - Bee } \\
\mathrm{mA}\end{array}$ & $\begin{array}{c}250 \\
\mathrm{~mA}\end{array}$ & $200 \mathrm{~mA} * 1$ & $\begin{array}{c}200 \\
\mathrm{~mA}\end{array}$ \\
\hline 4 & $\begin{array}{c}\text { Servos (HS } \\
422)\end{array}$ & $\begin{array}{c}120 \\
\mathrm{~mA}\end{array}$ & $50 \%$ & $60 \mathrm{~mA} * 2$ & $\begin{array}{c}120 \\
\mathrm{~mA}\end{array}$ \\
\hline 5 & $\begin{array}{c}\text { Wheel Drive } \\
\text { Motors }\end{array}$ & $\begin{array}{c}250 \\
\mathrm{~mA}\end{array}$ & $100 \%$ & $250 \mathrm{~mA} * 1$ & $\begin{array}{c}250 \\
\mathrm{~mA}\end{array}$ \\
\hline 6 & $\begin{array}{c}\text { Microcontroller } \\
\text { PCB (Arduino } \\
\text { V3) }\end{array}$ & $\begin{array}{c}100 \\
\mathrm{~mA}\end{array}$ & $100 \%$ & $100 \mathrm{~mA} * 1$ & $\begin{array}{c}100 \\
\mathrm{~mA}\end{array}$ \\
\hline 7 & Encoders & $4 \mathrm{~mA}$ & $100 \%$ & $4 \mathrm{~mA} * 2$ & $8 \mathrm{~mA}$ \\
\hline 8 & $\begin{array}{c}\text { Miscellaneous } \\
150 \\
\mathrm{~mA}\end{array}$ & $100 \%$ & $150 \mathrm{~mA} * 1$ & $\begin{array}{c}150 \\
\mathrm{~mA}\end{array}$ \\
\hline 9 & $\begin{array}{c}\text { Ultrasonic } \\
\text { Sensor ( } \\
\text { Seeedstudio ) }\end{array}$ & $15 \mathrm{~mA}$ & $100 \%$ & $15 \mathrm{~mA} * 1$ & $\begin{array}{c}15 \\
\mathrm{~mA}\end{array}$ \\
\hline & & & & $\begin{array}{c}\mathrm{T} \text { Total } \\
\mathrm{mA}\end{array}$ \\
\hline
\end{tabular}

On this rover, a $2200 \mathrm{mAh}$ Lithium-Polymer battery is used to supply the power, and the total power consumed by robot = 815.1 mA. So the battery lifetime can be calculated as

Battery Life $=$ Battery Capacity/Total power consumed or required for robot

$$
\begin{aligned}
& =2200 \mathrm{mAh} / 815.1 \mathrm{~mA} \\
& =2.69 \mathrm{Hrs} .
\end{aligned}
$$

TABLE V TOTAL POWER CONSUMPTION FOR ROVER 3

\begin{tabular}{|c|c|c|c|c|c|}
\hline $\begin{array}{c}\text { Sr. } \\
\text { No. }\end{array}$ & Component & Rating & $\begin{array}{c}\text { Operating } \\
\text { Time }\end{array}$ & $\begin{array}{c}\text { Current } \\
\text { Consumption } \\
\text { * No of } \\
\text { Components }\end{array}$ & Total \\
\hline 1 & $\begin{array}{c}\text { Ultrasonic } \\
\text { Sensors( SRF2) }\end{array}$ & $4 \mathrm{~mA}$ & $70 \%$ & $2.8 \mathrm{~mA} * 2$ & $\begin{array}{c}5.6 \\
\mathrm{~mA}\end{array}$ \\
\hline 2 & $\begin{array}{c}\text { IR Sensors ( } \\
\text { Compound) }\end{array}$ & $20 \mathrm{~mA}$ & $50 \%$ & $10 \mathrm{~mA} * 1$ & $\begin{array}{c}10 \\
\mathrm{~mA}\end{array}$ \\
\hline
\end{tabular}

\begin{tabular}{|c|c|c|c|c|c|}
\hline 3 & $\begin{array}{c}\text { Camera ( } \\
\text { Blackfin ) }\end{array}$ & $\begin{array}{c}145 \\
\mathrm{~mA}\end{array}$ & $80 \%$ & $116 \mathrm{~mA} * 1$ & $\begin{array}{c}116 \\
\mathrm{~mA}\end{array}$ \\
\hline 4 & Servos HS 422 & $\begin{array}{c}120 \\
\mathrm{~mA}\end{array}$ & $50 \%$ & $60 \mathrm{~mA} * 3$ & $\begin{array}{c}180 \\
\mathrm{~mA}\end{array}$ \\
\hline 5 & $\begin{array}{c}\text { Wheel Drive } \\
\text { Motors }\end{array}$ & $\begin{array}{c}73.7 \\
\mathrm{~mA}\end{array}$ & $100 \%$ & $73.3 \mathrm{~mA} * 2$ & $\begin{array}{c}146.6 \\
\mathrm{~mA}\end{array}$ \\
\hline 6 & $\begin{array}{c}\text { Microcontroller } \\
\text { (Uno) }\end{array}$ & $50 \mathrm{~mA}$ & $100 \%$ & $50 \mathrm{~mA} * 1$ & $\begin{array}{c}50 \\
\mathrm{~mA}\end{array}$ \\
\hline 7 & $\begin{array}{c}\text { Ultrasonic } \\
\text { Sensor (Ping) }\end{array}$ & $20 \mathrm{~mA}$ & $100 \%$ & $20 \mathrm{~mA} * 1$ & $\begin{array}{c}20 \\
\mathrm{~mA}\end{array}$ \\
\hline 8 & $\begin{array}{c}\text { GPS/GPRS } \\
\mathrm{mA}\end{array}$ & $80 \%$ & $36 \mathrm{~mA} * 2$ & $\begin{array}{c}72 \\
\mathrm{~mA}\end{array}$ \\
\hline 9 & $\begin{array}{c}\text { Laser Range } \\
\text { Finder }\end{array}$ & $40 \mathrm{~mA}$ & $90 \%$ & $100 \mathrm{~mA} * 1$ & $\begin{array}{c}70 \\
\mathrm{~mA}\end{array}$ \\
\hline 10 & Miscellaneous & $\begin{array}{c}100 \\
\mathrm{~mA}\end{array}$ & $100 \%$ & $100 \mathrm{~mA} * 1$ & $\begin{array}{c}100 \\
\mathrm{~mA}\end{array}$ \\
\hline & & & & $\mathrm{Total}$ & $\begin{array}{c}770.2 \\
\mathrm{~mA}\end{array}$ \\
\hline
\end{tabular}

On this rover, a $2400 \mathrm{mAh}$ Lithium-Polymer battery is used to supply the power, and the total power consumed by robot $=$ $770.2 \mathrm{~mA}$. So the battery lifetime can be calculated as

Battery Life $=$ Battery Capacity/Total power consumed or required for robot

$$
\begin{aligned}
& =2400 \mathrm{mAh} / 770.2 \mathrm{~mA} \\
& =3.11 \mathrm{Hrs} .
\end{aligned}
$$

TABLE VI TOTAL POWER CONSUMPTION FOR ROVER 4

\begin{tabular}{|c|c|c|c|c|c|}
\hline $\begin{array}{c}\text { Sr. } \\
\text { No. }\end{array}$ & Component & Rating & $\begin{array}{c}\text { Operating } \\
\text { Time }\end{array}$ & $\begin{array}{c}\text { Current } \\
\text { Consumption } \\
\text { * No of } \\
\text { Components }\end{array}$ & Total \\
\hline 1 & $\begin{array}{c}\text { Ultrasonic } \\
\text { Sensor } \\
\text { (MaxSonar) }\end{array}$ & $3.1 \mathrm{~mA}$ & $80 \%$ & $2.48 \mathrm{~mA} * 2$ & $\begin{array}{c}4.96 \\
\mathrm{~mA}\end{array}$ \\
\hline 2 & $\begin{array}{c}\text { IR Sensors ( } \\
\text { Sharp ) }\end{array}$ & $33 \mathrm{~mA}$ & $50 \%$ & $16.5 \mathrm{~mA} * 1$ & $\begin{array}{c}16.5 \\
\mathrm{~mA}\end{array}$ \\
\hline 3 & $\begin{array}{c}\text { Camera } \\
\text { (Blackfin) }\end{array}$ & $\begin{array}{c}145 \\
\mathrm{~mA}\end{array}$ & $80 \%$ & $116 \mathrm{~mA} * 1$ & $\begin{array}{c}116 \\
\mathrm{~mA}\end{array}$ \\
\hline 4 & $\begin{array}{c}\text { Servos (HS 422 } \\
\text { ) }\end{array}$ & $\begin{array}{c}120 \\
\mathrm{~mA}\end{array}$ & $70 \%$ & $84 \mathrm{~mA} * 1$ & $84 \mathrm{~mA}$ \\
\hline 5 & $\begin{array}{c}\text { Wheel Drive } \\
\text { Motors }\end{array}$ & $\begin{array}{c}100 \\
\mathrm{~mA}\end{array}$ & $100 \%$ & $100 \mathrm{~mA} * 2$ & $\begin{array}{c}200 \\
\mathrm{~mA}\end{array}$ \\
\hline 6 & $\begin{array}{c}\text { Microcontroller } \\
\text { Uno }\end{array}$ & $50 \mathrm{~mA}$ & $100 \%$ & $50 \mathrm{~mA} * 1$ & $50 \mathrm{~mA}$ \\
\hline 7 & Encoder & $20 \mathrm{~mA}$ & $100 \%$ & $20 \mathrm{~mA} * 2$ & $40 \mathrm{~mA}$ \\
\hline 8 & $\begin{array}{c}\text { Laser Range } \\
\text { Finder }\end{array}$ & $40 \mathrm{~mA}$ & $90 \%$ & $36 \mathrm{~mA} * 2$ & $72 \mathrm{~mA}$ \\
\hline 9 & $\begin{array}{c}\text { X-Bee } \\
\mathrm{mA}\end{array}$ & $80 \%$ & $200 \mathrm{~mA} * 1$ & $\begin{array}{c}200 \\
\mathrm{~mA}\end{array}$ \\
\hline 10 & $\begin{array}{c}\text { Miscellaneous } \\
100 \\
\mathrm{~mA}\end{array}$ & $100 \%$ & $100 \mathrm{~mA} * 1$ & $\begin{array}{c}100 \\
\mathrm{~mA}\end{array}$ \\
\hline & & & $\begin{array}{c}\mathrm{Total} \\
\mathrm{mA}\end{array}$ \\
\hline
\end{tabular}

On this rover, a $2000 \mathrm{mAh}$ Lithium-Polymer battery is used to supply the power, and the total power consumed by robot $=$ $883.46 \mathrm{~mA}$. So the battery lifetime can be calculated as

Battery Life $=$ Battery Capacity/Total power consumed or required for robot

$$
\begin{aligned}
& =2000 \mathrm{mAh} / 883.46 \mathrm{~mA} \\
& =2.2 \mathrm{Hrs} .
\end{aligned}
$$


TABLE VII TOTAL POWER CONSUMPTION FOR 5 ROVERS

\begin{tabular}{|c|c|c|c|c|c|}
\hline $\begin{array}{l}\text { Sr. } \\
\text { No. }\end{array}$ & Component & Rating & $\begin{array}{c}\text { Operating } \\
\text { Time }\end{array}$ & $\begin{array}{c}\text { Current } \\
\text { Consumption } \\
* \text { No of } \\
\text { Components } \\
\end{array}$ & Total \\
\hline 1 & $\begin{array}{l}\text { Ultrasonic } \\
\text { Sensors }\end{array}$ & $4 \mathrm{~mA}$ & $70 \%$ & $2.8 \mathrm{~mA} * 2$ & $\begin{array}{l}5.6 \\
\mathrm{~mA}\end{array}$ \\
\hline 2 & $\begin{array}{l}\text { IR Sensors } \\
\text { (Sharp) }\end{array}$ & $33 \mathrm{~mA}$ & $50 \%$ & $16.5 \mathrm{~mA} * 1$ & $\begin{array}{l}16.5 \\
\mathrm{~mA}\end{array}$ \\
\hline 3 & Servos & $\begin{array}{l}120 \\
\mathrm{~mA}\end{array}$ & $70 \%$ & $84 \mathrm{~mA} * 1$ & $\begin{array}{r}84 \\
\mathrm{~mA} \\
\end{array}$ \\
\hline 4 & $\begin{array}{c}\text { Wheel Drive } \\
\text { Motors }\end{array}$ & $\begin{array}{l}100 \\
\mathrm{~mA}\end{array}$ & $100 \%$ & $100 \mathrm{~mA} * 2$ & $\begin{array}{l}200 \\
\mathrm{~mA}\end{array}$ \\
\hline 5 & $\begin{array}{c}\text { Microcontroller } \\
\text { Uno }\end{array}$ & $50 \mathrm{~mA}$ & $100 \%$ & $50 \mathrm{~mA} * 1$ & $\begin{array}{r}50 \\
\mathrm{~mA} \\
\end{array}$ \\
\hline 6 & Encoders & $20 \mathrm{~mA}$ & $100 \%$ & $20 \mathrm{~mA} * 2$ & $\begin{array}{r}40 \\
\mathrm{~mA}\end{array}$ \\
\hline 7 & X-Bee & $\begin{array}{l}250 \\
\mathrm{~mA}\end{array}$ & $80 \%$ & $200 \mathrm{~mA} * 1$ & $\begin{array}{l}200 \\
\mathrm{~mA}\end{array}$ \\
\hline \multirow[t]{2}{*}{8} & Miscellaneous & $\begin{array}{l}100 \\
\mathrm{~mA}\end{array}$ & $100 \%$ & $100 \mathrm{~mA} * 1$ & $\begin{array}{l}100 \\
\mathrm{~mA}\end{array}$ \\
\hline & & & & Total & $\begin{array}{c}696.1 \\
\mathrm{~mA}\end{array}$ \\
\hline
\end{tabular}

On this rover, a $2000 \mathrm{mAh}$ Lithium-Polymer battery is used to supply the power, and the total power consumed by robot $=$ $696.1 \mathrm{~mA}$. So the battery lifetime can be calculated as

Battery Life $=$ Battery Capacity/Total power consumed or required for $\operatorname{robot}=2000 \mathrm{mAh} / 696.1 \mathrm{~mA}=2.87 \mathrm{Hrs}$.

\section{EXPERIMENTAL RESULTS}

We have designed and built five robots as a part of the UB swarm and performed several experiments to demonstrate the system's feasibility. The fig. 6, 7, 8, and 9 shows the images of UB robot swarm after implementing and mounting all the sensors and actuators. The hardware architecture of UB robot swarm is reconfigurable and can be reassembled at any time. Also the hardware architecture is very flexible; we can connect any type of sensors without doing any modification to it. This robot swarm was tested for a set of different experiments such as object avoidance, object transportation, human rescue, wall painting and mapping.

From the calculated power as shown in tables 3, 4, 5, 6 and 7 , each robot consumes between $650 \mathrm{~mA}$ to $900 \mathrm{~mA}$, which ensures continuous operation for a minimum of at least three hours. For this experiment, we decided to take three different sets of measurements. The first set of measurement taken while the robot rover is with full load and full motion.

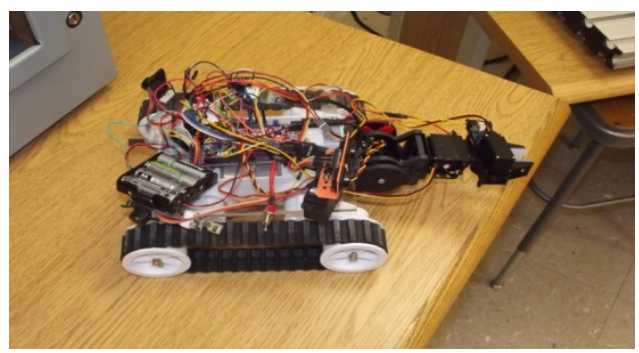

Fig. 6 UB Robot Rover 1

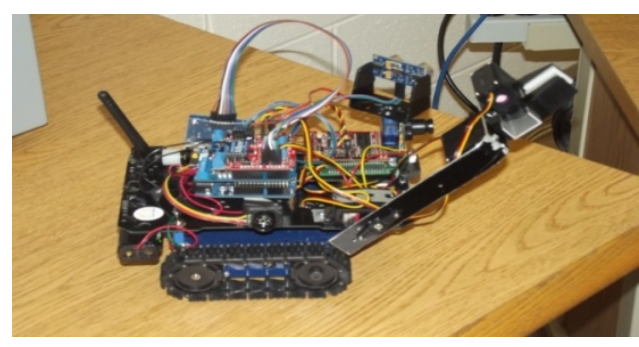

Fig. 7 UB Robot Rover 2

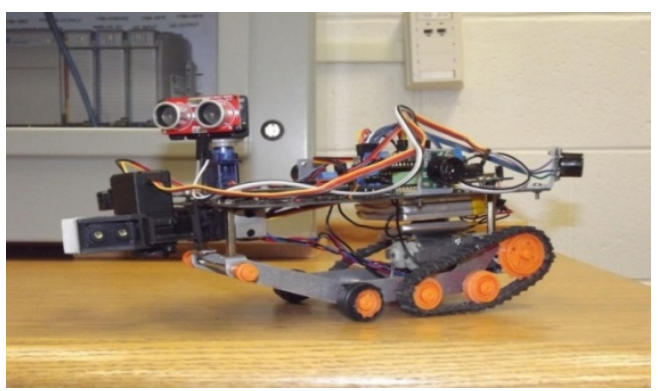

Fig. 8 UB Robot Rover 3
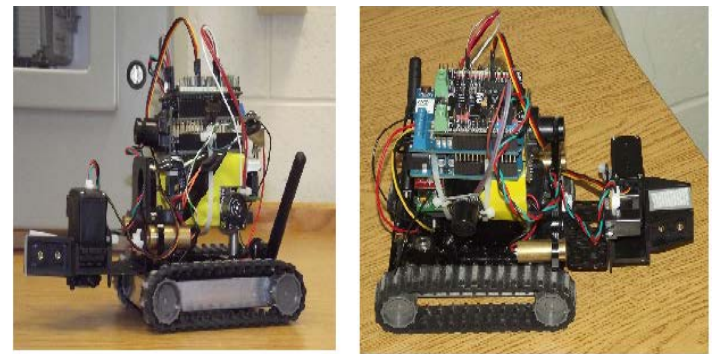

Fig. 9 UB Robot Rover 4 and 5

The full load means, all the sensors, actuators, communication units, and microprocessor are in $100 \%$ working mode. So in $100 \%$ working mode, the discharged rate of battery will be very fast and robot rover will perform a task for three hours only as shown in figure 10, 11, 12, 13, and 14 with a blue line. In the second set of measurements, the robot rover is in full motion with no load. In this experiment, only drive motors and only one sensor are in on mode while other sensors, actuators were in off mode. The discharged rate of battery is slower than the first case as shown in figure 10, 11, 12,13 , and 14 with a red line. The robot rover performs the task longer than in the first case. To save battery power, we decided to do power management on the robot rover by choosing which sensor and actuator should be on for task completion. So in the algorithm, we control the on and off action of sensors, actuators, and drive motors depending on the task. In this power management method, sensors, actuators, and other components will be on only when needed; otherwise, they will go in sleep mode so that we can save battery power. The experimental measurements were plotted on graph as shown in figure $10,11,12,13$, and 14 with a black line. We can see from the graph that robot performs task longer than the first two sets of measurements and the battery discharge rate is very slow. 


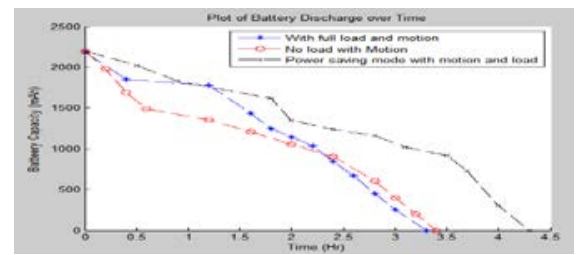

Fig. 10 Battery Capacity Vs Operating Time for Robot 1

For each robot of the UB swarm, current consumption is measured at different time intervals and plotted the graph in Matlab.

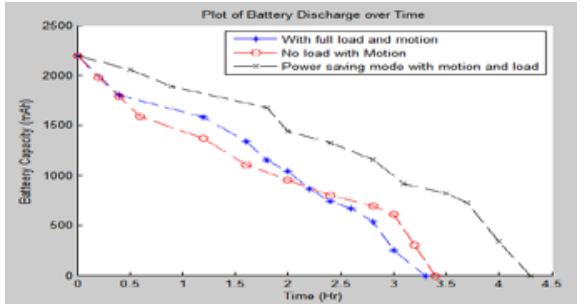

Fig. 11 Battery Capacity Vs Operating Time for Robot 2

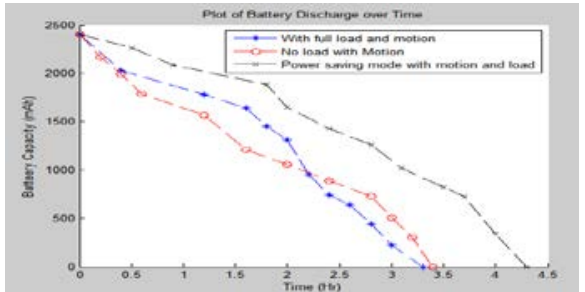

Fig. 12 Battery Capacity Vs Operating Time for Robot 3

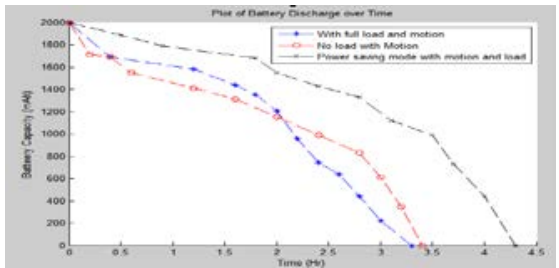

Fig. 13 Battery Capacity Vs Operating Time for Robot 4

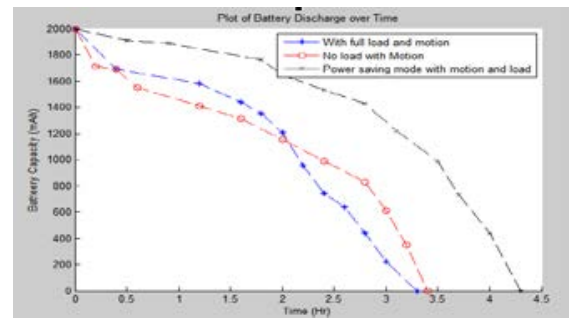

Fig. 14 Battery Capacity Vs Operating Time for Robot 5

\section{CONCLUSION}

UB swarm system consists of five robots which are heterogeneous in sensory units, microcontroller, functionality, and size. The proposed hardware architecture of heterogeneous robot swarm is designed, built and tested. We describe all the hardware components used to build UB robot swarm. The power consumption and management for UB swarm with fault detection is also addressed in this work. We also present the results obtained from this work. The UB
Swarm system uses both centralized and decentralized control strategies within the swarm. The robot-to-robot and robot-toenvironment interaction provides the task-oriented, simple collective swarm behavior.

\section{REFERENCES}

[1] D. F. M. Dorigo, L. M. Gambardella, F. Mondada, et al, "Swarmanoid: a novel concept for the study of heterogeneous robotic swarms," Institut de Recherches Interdisciplinaires et de D'eveloppements en Intelligence Artificielle Universite Libre de Bruxelles ' Av F. D. Roosevelt 50, CP 194/6 1050 Bruxelles, Belgium2011.

[2] C. Churavy, M. Baker, S. Mehta, I. Pradhan, N. Scheidegger, S. Shanfelt, R. Rarick, and D. Simon, "Effective implementation of a mapping swarm of robots," Potentials, IEEE, vol. 27, pp. 28-33, 2008.

[3] M. Patil, T. Abukhalil, and T. Sobh, "Hardware Architecture Review of Swarm Robotics System: Self-Reconfigurability, Self-Reassembly, and Self-Replication," ISRN Robotics, vol. 2013, p. 11, 2013.

[4] E. M. H. Zahugi, A. M. Shabani, and T. V. Prasad, "Libot: Design of a low cost mobile robot for outdoor swarm robotics," in Cyber Technology in Automation, Control, and Intelligent Systems (CYBER), 2012 IEEE International Conference on, 2012, pp. 342-347.

[5] P. B.-T. Paul Moubarak, "Modular and reconfigurable mobile robotics," Journal Robotics and Autonomous Systems archive, vol. 60 pp. 16481663 December, 2012.

[6] F. Mondada, Guignard, A., Bonani, M., Bar, D., Lauria, M. \& Floreano, D. Citeseer,, "Swarmbot: From concept to implementation," in Proceedings of the 2003 IEEE/RSJ International Conference on Intelligent Robot and Systems (IROS 2003),, 2003., pp. 1626-1631.

[7] M. D. E. Bonabeau, and G. Theraulaz. (1999) Swarm Intelligence: From Natuarl to Articial Systems.

[8] J. L. C. W. Zecha, and W. Claupein, "Mobile sensor platforms: categorisation and research applications in precision farming," J. Sens. Sens. Syst., vol. 2, pp. 51-72, 2013.

[9] H. R. E. J. Borenstein, L. Feng, and D. Wehe, "Mobile Robot Positioning \& Sensors and Techniques," Journal of Robotic Systems, Special Issue on Mobile Robots, vol. 14, pp. 231-249.

[10] G. A. D. C. F. Ducatelle, C. Pinciroli, F. Mondada and L.M. Gambardella, "Communication assisted navigation in robotic swarms: self-organization and cooperation," Dalle Molle Institute for Articial Intelligence, Galleria 2, 6928 Manno, Switzerland IDSIA-01-11, 2011.

[11] C. M. F. Micael S. Couceiro, J. Miguel A. Luz, Nuno M. F. Ferreira, Rui P. Rocha, "A Low-Cost Educational Platform for Swarm Robotics," International Journal of Robots, Education and Art(IJREA), vol. 2, February 2012.

[12] M. P. T. S. Tamer Abukhalil, "A Comprehensive Survey on Decentralized Modular Swarm Robotic systems and Deployment Environments " International Journal of Engineering (IJE), vol. 7 pp. 44-60, 2013.

[13] S. N. a. H. A. A. Michelle McPartland, "Emergence of Communication in Competitive Multi-Agent Systems: A Pareto Multi-Objective Approach," in GECCO’05, Washington, DC, USA. , 2005, pp. 51-58.

[14] " RobotShop Distribution inc.," ed. 